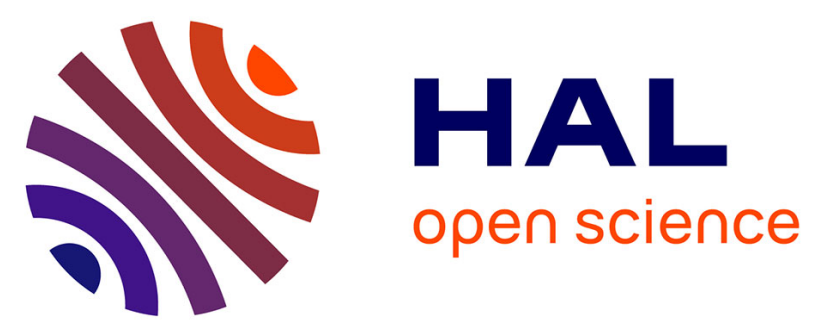

\title{
Corrosion and Hydrogen Permeation in H2S Environments with O2 Contamination, Part 2: Impact of H2S Partial Pressure
}

Martien Duvall Deffo Ayagou, Gaurav R Joshi, Thi Tuyet Mai Tran, Eliane Sutter, Bernard Tribollet, Christophe Mendibide, Claude Duret-Thual, Nicolas Ferrando, Jean Kittel

\section{To cite this version:}

Martien Duvall Deffo Ayagou, Gaurav R Joshi, Thi Tuyet Mai Tran, Eliane Sutter, Bernard Tribollet, et al.. Corrosion and Hydrogen Permeation in H2S Environments with O2 Contamination, Part 2: Impact of H2S Partial Pressure. Corrosion, 2019, 75 (4), pp.389-397. 10.5006/3092 . hal-02157852

\section{HAL Id: hal-02157852 \\ https://hal-ifp.archives-ouvertes.fr/hal-02157852}

Submitted on 17 Jun 2019

HAL is a multi-disciplinary open access archive for the deposit and dissemination of scientific research documents, whether they are published or not. The documents may come from teaching and research institutions in France or abroad, or from public or private research centers.
L'archive ouverte pluridisciplinaire HAL, est destinée au dépôt et à la diffusion de documents scientifiques de niveau recherche, publiés ou non, émanant des établissements d'enseignement et de recherche français ou étrangers, des laboratoires publics ou privés.

\section{(c)(1)}

Distributed under a Creative Commons Attribution| 4.0 International License 


\title{
Corrosion and Hydrogen Permeation in $\mathrm{H}_{2} \mathrm{~S}$ Environments with $\mathrm{O}_{2}$ Contamination, Part 2: Impact of $\mathrm{H}_{2} \mathrm{~S}$ Partial Pressure
}

\author{
Martien Duvall Deffo Ayagou, ${ }^{*}$ Gaurav R. Joshi, ${ }^{* *}$ Thi Tuyet Mai Tran, ${ }^{* * *}$ Eliane Sutter, ${ }^{* * *}$ Bernard Tribollet, ${ }^{* * *}$ \\ Christophe Mendibide, ${ }^{*}$ Claude Duret-Thual, ${ }^{*}$ Nicolas Ferrando, ${ }^{* * * *}$ and Jean Kitte ${ }^{\ddagger * * *}$
}

\begin{abstract}
Materials selection in the oil and gas industry relies on engineering standards, such as NACE TM0177 and NACE TMO284, which stipulate that oxygen contamination should be avoided during materials testing in $\mathrm{H}_{2} \mathrm{~S}$-containing media. In this second paper, as part of a series of articles that evaluates how traces of oxygen modify the corrosion of pure iron and hydrogen permeation across iron membranes in $\mathrm{H}_{2} \mathrm{~S}$ containing solutions, the impact of changing the $\mathrm{H}_{2} \mathrm{~S}$ partial pressure from $100 \mathrm{kPa}$ to $0.1 \mathrm{kPa}$ was investigated. It was found that bulk solution chemistry for all $\mathrm{H}_{2} \mathrm{~S}$ partial pressures changes with time, due to the formation of $\mathrm{H}_{2} \mathrm{~S}-\mathrm{O}_{2}$ reaction products (sulfates, sulfites, and thiosulfates), which results in bulk solution acidification. Electrochemical and weight-loss measurements confirm that Fe corrosion rates in baseline well-deaerated $\mathrm{H}_{2} \mathrm{~S}$-containing solutions decrease with decreasing $\mathrm{H}_{2} \mathrm{~S}$ partial pressure, although these are observed to be much higher under continuous oxygen contamination. With decreasing $\mathrm{H}_{2} \mathrm{~S}$ partial pressure, hydrogen uptake in Fe also decreases, due to lower and lower concentrations of dissolved $\mathrm{H}_{2} \mathrm{~S}$ and the associated increase in $\mathrm{pH}$. However, even at $1 \mathrm{kPa}$ and $0.1 \mathrm{kPa} \mathrm{H}_{2} \mathrm{~S}$, permeation effciencies remain close to $100 \%$ when no $\mathrm{O}_{2}$ contamination is present. The hydrogen uptake is always relatively lower in Fe exposed to oxygen-polluted $\mathrm{H}_{2} \mathrm{~S}$ solutions. Permeation efficiencies decrease continuously. From electrochemical data and surface characterization, these observations at lower $\mathrm{H}_{2} \mathrm{~S}$ partial pressures are attributed to the disruptive effect of oxygen on the nature of sulfide corrosion products, and hydrogen entry promotion, along with the contribution of an additional cathodic reaction that does not result in hydrogen entry into the metal.
\end{abstract}

KEY WORDS: hydrogen-induced cracking, hydrogen permeation, hydrogen sulfide, sulfide stress cracking

\section{INTRODUCTION}

T he extent of the degradation of carbon and low-alloy steel components during upstream production varies across a plethora of environmental and operating conditions. Factors such as acid gas concentration, solution chemistry, fluid flow regimes, and oil/water cut influence engineering decisions that range from materials selection to inhibitor dosing. Ferritic materials exposed to environments containing hydrogen sulfide $\left(\mathrm{H}_{2} \mathrm{~S}\right)$ can suffer hydrogen-induced cracking, sulfide stress cracking (SSC), or stress-oriented hydrogen-induced cracking. This is correctly attributed to the corrosive, and H-entry promoting nature, of dissolved $\mathrm{H}_{2} \mathrm{~S}$.

ISO 15156 guides the selection of carbon and low-alloy steels for use in existing or potential sour operating conditions. ${ }^{1}$ Often, a $\mathrm{pH}(\mathrm{y})-\mathrm{P}_{\mathrm{H}_{2} \mathrm{~S}}(\mathrm{x})$ diagram (see ISO 15156-2) is used as a frame of reference during materials testing; the diagram plots solution acidity $(\mathrm{pH})$ vs. $\mathrm{H}_{2} \mathrm{~S}$ partial pressures $(\mathrm{kPa})$ across orders of magnitude and suggests relative "levels of severity." Concerning materials qualification, standards such as NACE TM0177 and TM0284 stipulate materials testing criteria. A critical one is the effective deaeration of $\mathrm{H}_{2} \mathrm{~S}$-containing test solutions and maintaining low dissolved concentrations of oxygen during the testing period (typically $30 \mathrm{~d}$ ). ${ }^{2-3}$ Standards mention that, " $\mathrm{O}_{2}$ contamination may induce an increase of the corrosion rate and reduce hydrogen evolution and hydrogen entry into the steel," although "systematic studies of the parameters affecting these phenomena have not been reported in the literature." Ambient oxygen has the potential to pollute a test medium through incorrect or insufficient deaeration of the initial test solution, a poor sealing of test reactors, the use of plastic tubing permeable to oxygen, and a multitude of operations during the test (e.g., solution sampling, pH adjustment). From an industrial point of view, oxygen ingress into sour systems through compressors or vapor recovery units is well recognized. ${ }^{4}$

In the first paper of this series, it was shown how traces of oxygen exacerbate the corrosion of, but diminish the hydrogen permeation across, iron membranes exposed to $35 \mathrm{~g} / \mathrm{L} \mathrm{NaCl}$ saturated with $\mathrm{H}_{2} \mathrm{~S}$ at $24^{\circ} \mathrm{C}$ and atmospheric pressure (partial pressure of hydrogen sulfide gas $=100 \mathrm{kPa}$ ) as a function of time over 3 to 4 weeks. ${ }^{5}$ In this second paper, with the $\mathrm{pH}-\mathrm{P}_{\mathrm{H}_{2} \mathrm{~S}}$ diagram of ISO 15156 in mind, the study parameters are extended to lower applied $\mathrm{P}_{\mathrm{H}_{2} \mathrm{~S}}$ i.e., how the same $\mathrm{O}_{2}$ contamination influences phenomena in solutions containing lower dissolved $\mathrm{H}_{2} \mathrm{~S}$. As done in the first paper, only model systems are considered

\footnotetext{
Submitted for publication: November 5, 2018. Revised and accepted: December 22, 2018. Preprint available online: December 22, 2018,

https://doi.org/10.5006/3092.

‡ Corresponding author. E-mail: jean.kittel@ifpen.fr.

* Institut de la Corrosion Site de Saint-Etienne, ZA du parc secteur Gampille, Fraisses F-42490, France.

** IFP Energies Nouvelles, Rond point de l'échangeur de Solaize BP3, Solaize F-69360, France.

*** Sorbonne Université, CNRS, Laboratoire Interfaces et Systèmes Electrochimiques (LISE), Paris F-75005, France.

**** IFP Energies Nouvelles, 1 et 4 avenue de bois préau, Rueil-Malmaison F-92852, France.
} 


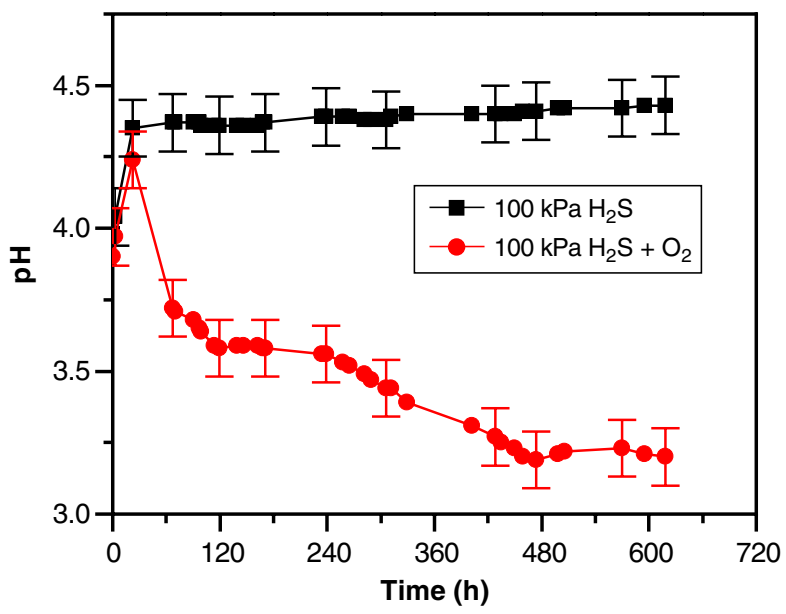

(a)

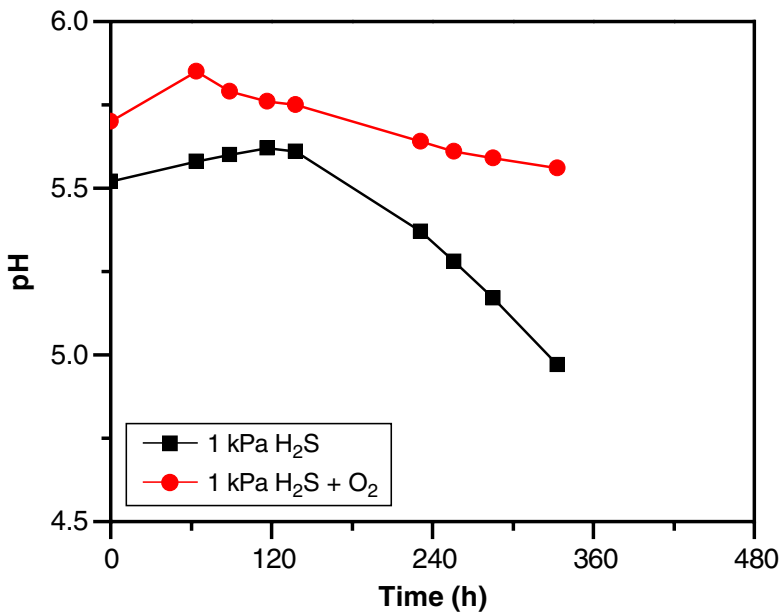

(c)

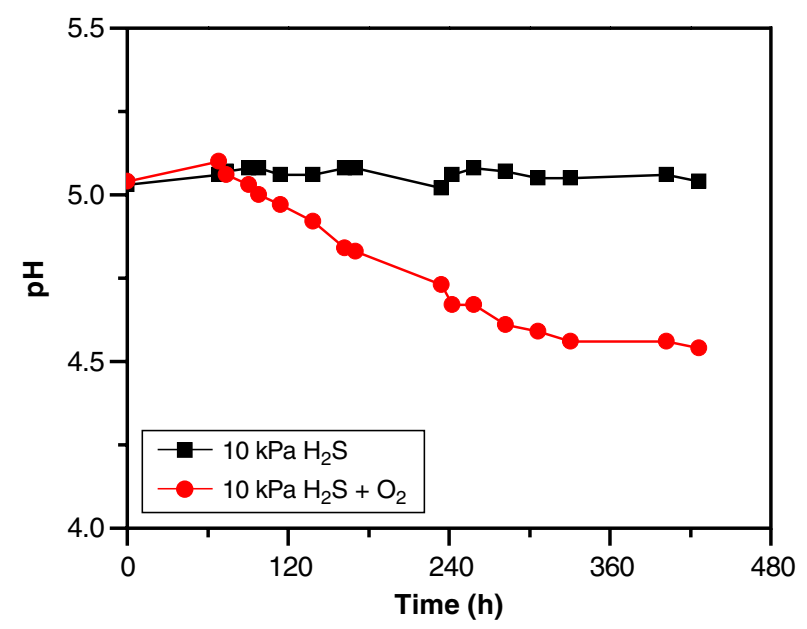

(b)

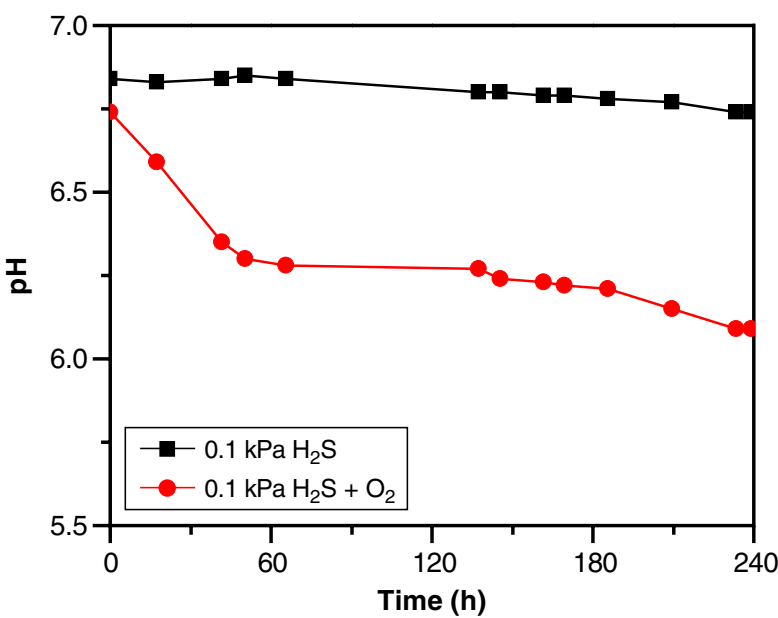

(d)

FIGURE 1. Time evolution of $\mathrm{pH}$ of test solutions at various $\mathrm{H}_{2} \mathrm{~S}$ partial pressures. Impact of continuous $\mathrm{O}_{2}$ contamination corresponding to $500 \mathrm{ppb}$ weight $\left(\mathrm{P}_{\mathrm{O}_{2}}=1.3 \mathrm{kPa}\right)$.

here, with pure iron as the test material, the use of unbuffered test solutions, and $\mathrm{H}_{2} \mathrm{~S}$ or $\mathrm{H}_{2} \mathrm{~S} / \mathrm{N}_{2}$ mixtures used to control the acid gas concentration (no $\mathrm{CO}_{2}$ ). As before, this study follows the evolution of the solution chemistries, and the effect on Fe corrosion and hydrogen uptake, as a function of time. Material surface characterization through $\mathrm{x}$-ray diffraction (XRD) further enables the understanding of phenomena that take place in such media.

\section{EXPERIMENTAL PROCEDURES}

The relevant preparation and experimental procedures are detailed in Part $1 .{ }^{5}$ Pure $\mathrm{H}_{2} \mathrm{~S}\left(>99.5 \% \mathrm{H}_{2} \mathrm{~S}\right)$ and $\mathrm{H}_{2} \mathrm{~S} / \mathrm{N}_{2}$ gas cylinders $\left(10 \% \mathrm{H}_{2} \mathrm{~S} /\right.$ balance $\left.\mathrm{N}_{2}\right),\left(1 \% \mathrm{H}_{2} \mathrm{~S} /\right.$ balance $\left.\mathrm{N}_{2}\right)$, and $\left(0.1 \% \mathrm{H}_{2} \mathrm{~S} /\right.$ balance $\left.\mathrm{N}_{2}\right)$ were used to establish the different partial pressures of $10 \mathrm{kPa}, 1 \mathrm{kPa}$, and $0.1 \mathrm{kPa}$, respectively, in the tests. The partial pressure of water vapor at $24^{\circ} \mathrm{C}$ being $3 \mathrm{kPa}$, a strict calculation of $\mathrm{H}_{2} \mathrm{~S}$ partial pressures leads to a $4 \%$ decrease in the reported values. For the sake of simplicity, rounded values were kept for $\mathrm{P}_{\mathrm{H}_{2} \mathrm{~S}}$ mentioned in the text. In order to determine the impact of $\mathrm{O}_{2}$ contamination, a number of tests were conducted with pure iron exposed to $35 \mathrm{~g} / \mathrm{L} \mathrm{NaCl}$ solution at various $\mathrm{H}_{2} \mathrm{~S}$ partial pressures $\left(\mathrm{P}_{\mathrm{H}_{2} \mathrm{~S}}\right)$ between $100 \mathrm{kPa}$

\footnotetext{
t Trade name.
}

and $0.1 \mathrm{kPa}$. Several types of measurements were performed: (1) continuous in situ $\mathrm{pH}$ measurement and periodic sampling of test solution for chemical analysis; (2) weight-loss and surface analysis of small coupons; (3) electrochemical impedance spectroscopy (EIS) at the H-entry face of the membrane; and (4) hydrogen permeation at the $\mathrm{H}$-exit face of the membrane.

\section{RESULTS AND DISCUSSION}

\section{1 / Impact of Oxygen on Corrosive Medium}

The evolution of test solution $\mathrm{pH}$ with or without oxygen contamination are shown in Figure 1. The tests at $100 \mathrm{kPa}$ were repeated four times, and the deviation of $\mathrm{pH}$ values was always less than \pm 0.1 (Figure 1[a]). The tests at lower $\mathrm{P}_{\mathrm{H}_{2} \mathrm{~S}}$ were performed only once, hence no error bars are plotted in the corresponding graphs. Note that as the balance gas is nitrogen, the bulk solution $\mathrm{pH}$ is higher at lower $\mathrm{P}_{\mathrm{H}_{2} \mathrm{~S}}$.

For exposure times of a few hours, no difference in $\mathrm{pH}$ is measured between the test with $\mathrm{O}_{2}$ contamination (red symbols) and the reference test without $\mathrm{O}_{2}$ (black symbols). Initial pH values are determined by acid gas content (i.e., $\mathrm{P}_{\mathrm{H}_{2} \mathrm{~S}}$ ), while FeS solubility equilibrium controls the final $\mathrm{pH}$, for the test condition without $\mathrm{O}_{2}$. For comparison, saturated $\mathrm{pH}$ values calculated with Cormed ${ }^{\mathrm{TM}^{\dagger}}$ are reported in Table 1, and compared with 
Table 1. Comparison Between Experimental $\mathrm{pH}$ at the Beginning of the Tests and Calculated $\mathrm{pH}$ at FeS Saturation in $35 \mathrm{~g} / \mathrm{L} \mathrm{NaCl}$ Solution at $24^{\circ} \mathrm{C}$

\begin{tabular}{|l|l|l|l|l|}
\hline $\mathbf{P}_{\mathbf{H}_{\mathbf{2}} \mathbf{S}} \mathbf{( k P a )}$ & $\mathbf{1 0 0}$ & $\mathbf{1 0}$ & $\mathbf{1}$ & $\mathbf{0 . 1}$ \\
\hline Exp. pH at 24 h without $\mathrm{O}_{2}$ & $4.3 \pm 0.1$ & 5.0 & 5.7 & 6.8 \\
\hline Exp. pH at 24 $\mathrm{h}$ with $\mathrm{O}_{2}$ & $4.2 \pm 0.1$ & 5.0 & 5.5 & 6.7 \\
\hline Calculated pH at FeS saturation & 4.3 & 5.0 & 5.6 & 6.3 \\
\hline
\end{tabular}

experimental values at short exposures. Except at the lowest $\mathrm{P}_{\mathrm{H}_{2} \mathrm{~S}}$ an excellent match is found between experimental and calculated values. As expected, reference tests without $\mathrm{O}_{2}$ contamination exhibit no significant changes of $\mathrm{pH}$ with time, once the saturated value is reached. On the contrary, $\mathrm{O}_{2}$ contamination systematically induces an acidification of the test solution over time. The rate of $\mathrm{pH}$ drop is greatest for the $100 \mathrm{kPa}$ case, and approximately similar for the remaining $\mathrm{P}_{\mathrm{H}_{2} \mathrm{~S}}$ systems, found to lie between $0.15 \mathrm{pH}$ and $0.3 \mathrm{pH}$ unit per $100 \mathrm{~h}$ exposure. Considering the usual duration of a standard SSC test $(720 \mathrm{~h})$, a pH drop more than $1 \mathrm{pH}$ unit may thus be anticipated under a comparable oxygen ingress.

In order to measure the $\mathrm{O}_{2}-\mathrm{H}_{2} \mathrm{~S}$ reaction chemistry, which is responsible for solution acidification, ${ }^{5}$ periodic sampling of the test solution was performed for the experiments at $100 \mathrm{kPa}$ $\mathrm{H}_{2} \mathrm{~S}$ and $10 \mathrm{kPa} \mathrm{H}_{2} \mathrm{~S}$. Analysis by ionic chromatography shows that sulfate $\left(\mathrm{SO}_{4}^{2-}\right)$ is the main species formed. Its concentration increased linearly with time in presence of $\mathrm{O}_{2}$ contamination, while it stayed at minute levels in reference conditions without $\mathrm{O}_{2}$ (Figure 2). According to the literature, the reaction paths leading to sulfate involves intermediate steps with thiosulfate formation accompanied by the release of $\mathrm{H}^{+}: 6-7$

$$
2 \mathrm{H}_{2} \mathrm{~S}+2 \mathrm{O}_{2} \rightarrow \mathrm{S}_{2} \mathrm{O}_{3}^{2-}+\mathrm{H}_{2} \mathrm{O}+2 \mathrm{H}^{+}
$$

The more stable sulfate species, and elemental sulfur, may then be formed by various paths, e.g., by direct oxidation:

$$
\mathrm{S}_{2} \mathrm{O}_{3}^{2-}+1 / 2 \mathrm{O}_{2} \rightarrow \mathrm{SO}_{4}^{2-}+\mathrm{S}
$$

Thiosulfate is also recognized as a candidate for direct reduction, either as only cathodic reactant, or in combination

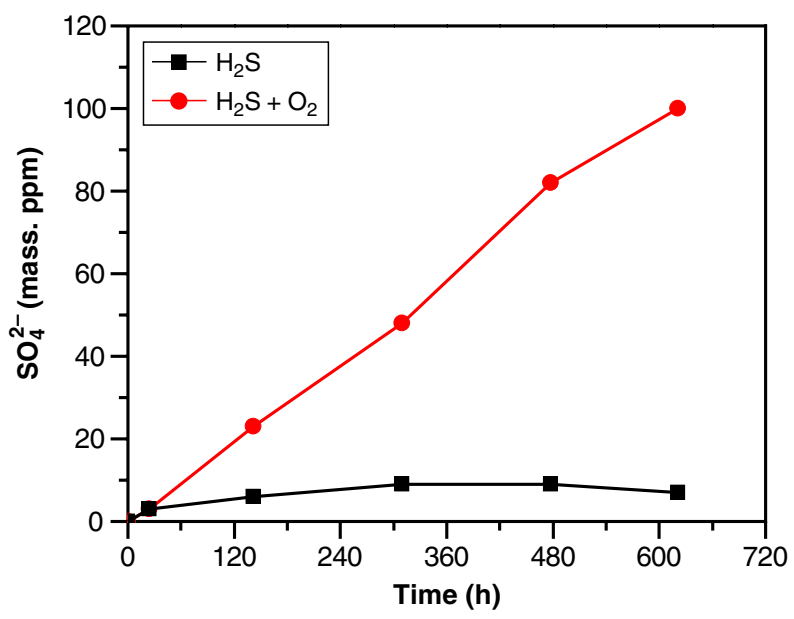

(a) with atomic hydrogen already present at the surface of the electrode: ${ }^{8}$

$$
\begin{gathered}
\mathrm{S}_{2} \mathrm{O}_{3}^{2-}+2 \mathrm{e}^{-} \rightarrow \mathrm{S}^{2-}+\mathrm{SO}_{3}^{2-} \\
\mathrm{S}_{2} \mathrm{O}_{3}^{2-}+\mathrm{H}_{\text {ads }}+\mathrm{e}^{-} \rightarrow \mathrm{S}^{2-}+\mathrm{SO}_{3}^{2-}+\mathrm{H}^{+}
\end{gathered}
$$

In this latter case, thiosulfate reduction plays a detrimental role in hydrogen diffusion into the metal, as it reacts with the intermediate species $\mathrm{H}_{\text {ads. }}$.

Such results of $\mathrm{pH}$ change could be indicative of $\mathrm{O}_{2}$ contamination during SSC qualification tests. Indeed, NACE TM0177 states that "oxygen contamination is evident by a cloudy (opaque) appearance of the test solution when the $\mathrm{H}_{2} \mathrm{~S}$ gas enters the test vessel." As soon as steel is present, darkening of the test solution occurs with iron sulfide precipitation, masking any transparency changes that take place in the early stages. The present authors suggest that in situ $\mathrm{pH}$ monitoring or chemical detection of sulfates might thus represent more robust methods to detect oxygen contamination in such systems.

\section{2 / Weight-Loss Corrosion and Surface Analysis}

The weight-loss corrosion rates of pure iron (average of two coupons) exposed to solutions at various $\mathrm{P}_{\mathrm{H}_{2} \mathrm{~S}}$, with and without $\mathrm{O}_{2}$ contamination, are compared in Table 2. Four replicates were performed under $100 \mathrm{kPa} \mathrm{H}_{2} \mathrm{~S}$, from which standard deviations were determined. All other tests were performed only once. This table also includes corrosion rates obtained from electrochemical measurements at the entry face of the membrane. The increasing discrepancy between weight-loss and electrochemical measurements, with decreasing $\mathrm{P}_{\mathrm{H}_{2} \mathrm{~S}}$, will be discussed in the electrochemical section of this article.

Corrosion rates in reference conditions without $\mathrm{O}_{2}$ decrease monotonically as $\mathrm{P}_{\mathrm{H}_{2} \mathrm{~S}}$ decreases. The corrosion rate drops from $0.5 \mathrm{~mm} / \mathrm{y}\left(100 \mathrm{kPa} \mathrm{H}_{2} \mathrm{~S}\right)$ to $0.1 \mathrm{~mm} / \mathrm{y}$ at $0.1 \mathrm{kPa} \mathrm{H}_{2} \mathrm{~S}$. This decrease of corrosion rate correlates with the measured increase in $\mathrm{pH}$. This is expected, because dissociated $\mathrm{H}^{+}$aq is one of the cathodic reactants. ${ }^{9}$ Indeed, the concentration of dissolved $\mathrm{H}_{2} \mathrm{~S}$ is expected to decrease from $1 \times 10^{-1} \mathrm{M}$ to $1 \times$ $10^{-4} \mathrm{M}$ from $100 \mathrm{kPa}$ to $0.1 \mathrm{kPa}$, which also is recognized as a relevant oxidizing agent that contributes to iron corrosion. ${ }^{10}$

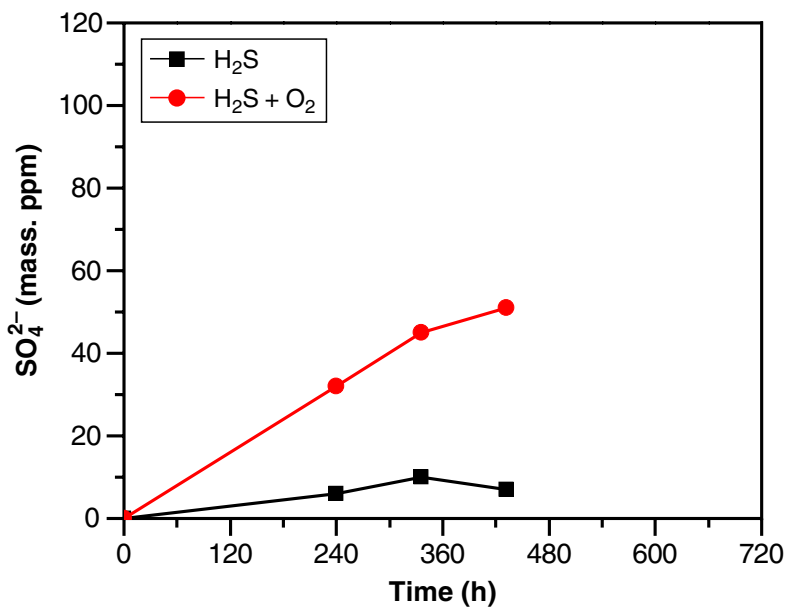

(b)

FIGURE 2. Time evolution of sulfate concentration for the tests at $100 \mathrm{kPa}$ and $10 \mathrm{kPa} \mathrm{H}_{2} \mathrm{~S}$ in model systems. 
Table 2. Impact of $\mathrm{O}_{2}$ Contamination on Corrosion Rate of Pure Iron Weight-Loss Coupons Exposed to $35 \mathrm{~g} / \mathrm{L} \mathrm{NaCl}$ Solution Saturated with $\mathrm{H}_{2} \mathrm{~S}$ at Various Partial Pressures for 2 to 4 Weeks

\begin{tabular}{|l|l|l|l|l|}
\hline & \multicolumn{2}{|l|}{$\begin{array}{l}\text { Corrosion Rates } \\
\text { Without } \mathbf{O}_{\mathbf{2}}(\boldsymbol{\mu} \mathbf{m} / \mathbf{y})\end{array}$} & \multicolumn{2}{l|}{$\begin{array}{l}\text { Corrosion Rates } \\
\text { with } \mathbf{O}_{\mathbf{2}}(\boldsymbol{\mu m} / \mathbf{y})\end{array}$} \\
\cline { 2 - 5 } $\mathbf{P}_{\mathbf{H}_{\mathbf{2}} \mathbf{S}}$ & Weight-Loss & EIS & Weight-Loss & EIS \\
\hline $100 \mathrm{kPa}$ & $489 \pm 68$ & 490 & $976 \pm 248$ & 900 \\
\hline $10 \mathrm{kPa}$ & 284 & 230 & 523 & 330 \\
\hline $1 \mathrm{kPa}$ & 163 & 53 & 2,257 & 96 \\
\hline $0.1 \mathrm{kPa}$ & 101 & 4 & 1,111 & 44 \\
\hline
\end{tabular}

It is expected that the water reduction reaction also becomes a relevant contributing cathodic reaction at the highest $\mathrm{pH} /$ /lowest $\mathrm{P}_{\mathrm{H}_{2} \mathrm{~S}}$ test solutions.

In the presence of $\mathrm{O}_{2}$ contamination, a systematic aggravation of corrosion is seen, compared to reference condition without $\mathrm{O}_{2}$. At $\mathrm{P}_{\mathrm{H}_{2} \mathrm{~S}}$ of $100 \mathrm{kPa}$ and $10 \mathrm{kPa}$, corrosion rates in the presence of oxygen were doubled. Curiously, however, the amplitude of this aggravation increases by more than an order of magnitude $(>10 \times)$ as $\mathrm{P}_{\mathrm{H}_{2} \mathrm{~S}}$ decreases even further toward the lowest dissolved $\mathrm{H}_{2} \mathrm{~S}$ concentrations and highest $\mathrm{pH}$. To discuss that the measured increase is not a result of "classical" oxygen cathodic corrosion, the concentrations of the dissolved molarities are considered in bulk solution. For the $100 \mathrm{kPa}$ and $10 \mathrm{KPa}$ systems, the $\left[\mathrm{H}_{2} \mathrm{~S}\right]_{\mathrm{aq}}$ are $0.1 \mathrm{M}$ and $0.01 \mathrm{M}$, respectively (vs. $2 \times 10^{-5} \mathrm{M}$ of $\left[\mathrm{O}_{2}\right]_{\text {aq }}$ ), i.e., in massive excess. In $1 \mathrm{kPa}$ and $0.1 \mathrm{kPa}$, the $\left[\mathrm{H}_{2} \mathrm{~S}\right]_{\mathrm{aq}}$ are $0.001 \mathrm{M}$ and $0.0001 \mathrm{M}$, respectively. The ratios of $\left[\mathrm{H}_{2} \mathrm{~S}\right]_{\mathrm{aq}}:\left[\mathrm{O}_{2}\right]_{\mathrm{aq}}$, which remain roughly the same throughout the testing period due to a continuous bubbling of both gases, decreased (from $5,000 \times$ to $5 \times$ ), but corrosion rates increased by an order of magnitude for the two lower $\mathrm{H}_{2} \mathrm{~S}$ partial pressures. This peculiarity of massively high corrosion rate is not explicable by $\left[\mathrm{O}_{2}\right]_{a q}$ as a cathodic reactant alone as it is simply not present in high enough concentration to support a high cathodic reduction current (of the order of $100 \mu \mathrm{A} / \mathrm{cm}^{2}$ ). The bulk solution acidification effect also contributes, but it is insufficient to cause more than a 10-fold increase in corrosion rates at the lowest $\mathrm{P}_{\mathrm{H}_{2} \mathrm{~S}}$.

In order to understand this curiousity, reference to surface characterization data is helpful. Figure 3 presents typical XRD patterns taken from $\mathrm{Fe}$ coupon surfaces that were exposed to solutions under high partial pressure $(100 \mathrm{kPa})$ and low partial pressure $(1 \mathrm{kPa}) \mathrm{H}_{2} \mathrm{~S}$, with and without oxygen contamination. For the $100 \mathrm{kPa}$ case, sample surfaces were comprised exclusively of iron sulfides, in particular mackinawite; under $500 \mathrm{ppb}$ oxygen contamination, additional signatures of mixture of pyrrhotite/pyrite/troillite were observed (it is difficult to distinguish between these as they share many diffraction peaks). At lower $\mathrm{P}_{\mathrm{H}_{2} \mathrm{~S}}$ of $10 \mathrm{kPa}$, iron sulfides, predominantly mackinawite, were detected. However, under oxygen contamination, one also can clearly discern the presence of magnetite and elemental sulfur $\left(\mathrm{S}_{8}\right)$ in addition to the iron sulfides (including greigite). Greigite is an iron sulfide mineral that is considered to form in the presence of traces of oxygen. ${ }^{11}$ This is quite significant as the surface products of elemental sulfur and magnetite are never detected at higher partial pressures of $\mathrm{H}_{2} \mathrm{~S}$. Indeed, elemental sulfur corrosion deposits are known to enormously accelerate the corrosion of iron, through galvanic coupling effects. ${ }^{4,12}$ It is expected to be particularly insidious

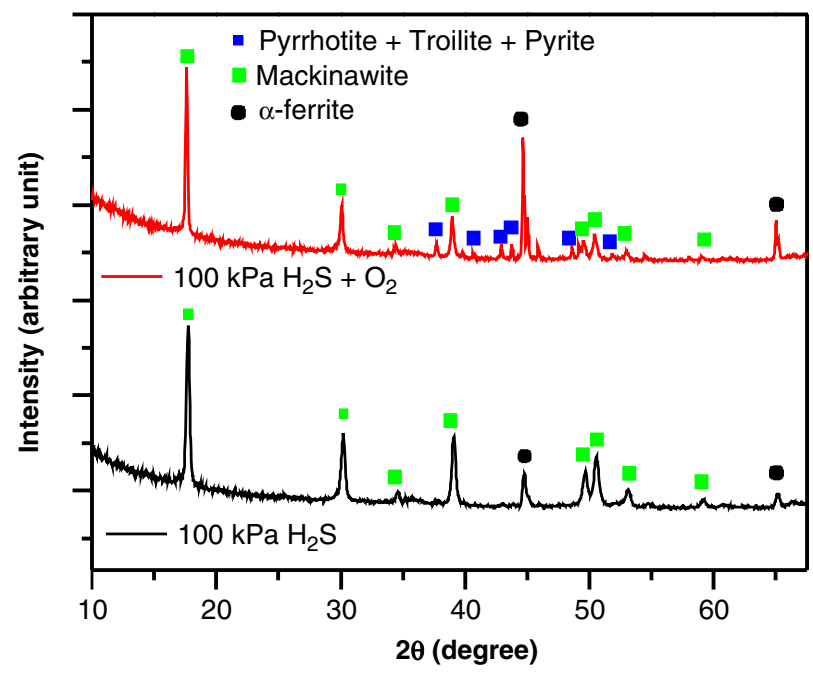

(a)

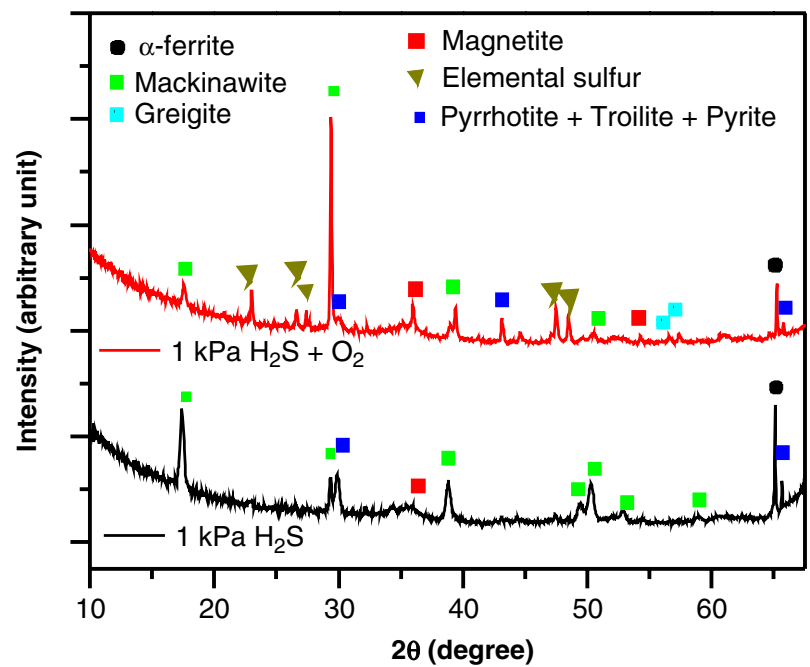

(b)

FIGURE 3. $X R D$ patterns from pure iron surfaces after long-term exposure to $\mathrm{H}_{2} \mathrm{~S}$-containing $35 \mathrm{~g} / \mathrm{L} \mathrm{NaCl}\left(24^{\circ} \mathrm{C}\right)$, with and without $500 \mathrm{ppb}$ oxygen contamination, at (a) $P_{\mathrm{H}_{2} \mathrm{~S}}=100 \mathrm{kPa}$ and (b) $1 \mathrm{kPa}$.

in field scenarios where an iron sulfide overlayer is exposed to salty brines. ${ }^{13}$ It may well explain why the highest weight-loss corrosion rates are detected at the lowest $\mathrm{H}_{2} \mathrm{~S}$ partial pressures. This experimental finding will be further discussed in the electrochemical section of this article.

\section{3 / Electrochemical Study}

In addition to weight-loss coupons, electrochemical measurements were conducted on the iron membrane. Typical EIS measurements of the entry face of the membrane at various times of exposure are presented in Figure 4. In this Figure, the plots labeled $(a, c, e$, and f) display EIS Nyquist spectra taken from sample surfaces exposed to different $\mathrm{P}_{\mathrm{H}_{2} \mathrm{~S}}$ solutions without oxygen, whereas the (b, $d, f$, and $h)$ plots show EIS data taken from surfaces exposed to the same (different) $\mathrm{P}_{\mathrm{H}_{2} \mathrm{~S}}$ solutions, albeit with oxygen contamination.

Except for the tests conducted at $100 \mathrm{kPa} \mathrm{H}_{2} \mathrm{~S}$ without $\mathrm{O}_{2}$ contamination and at long exposures (Figure 4[a]), all other EIS Nyquist curves are deemed to be quite comparable with each 


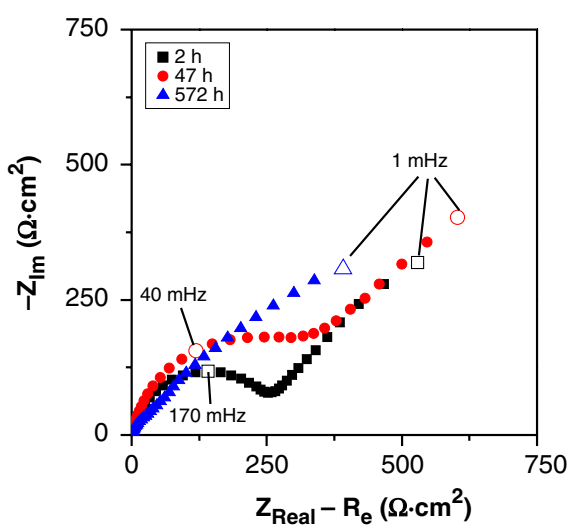

(a)

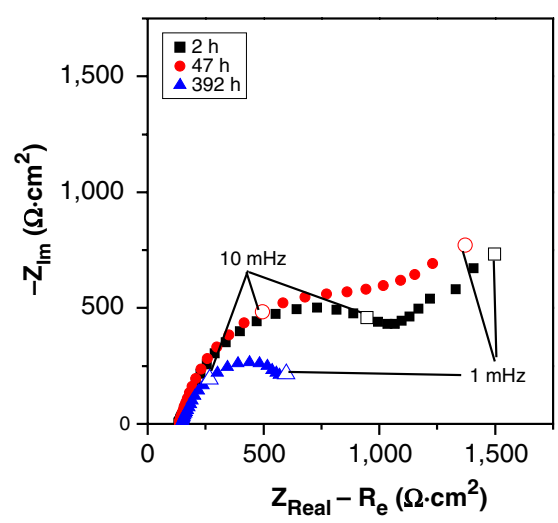

(d)

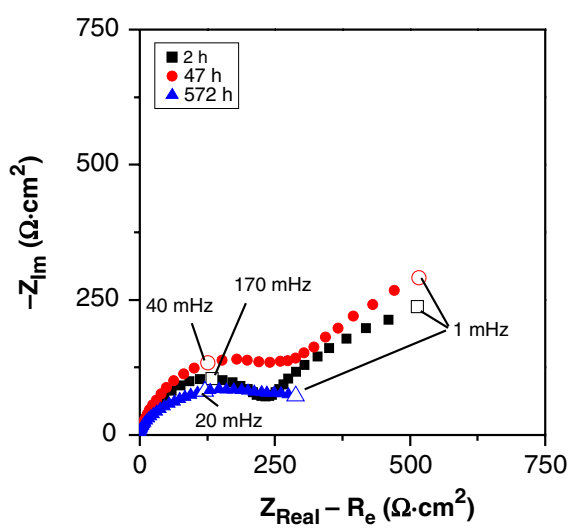

(b)

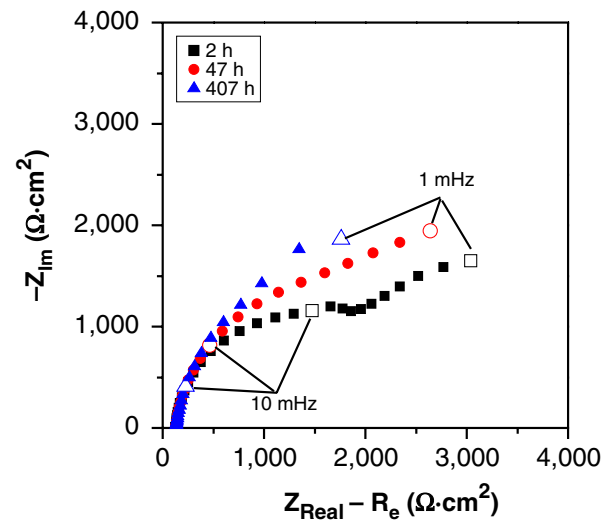

(e)

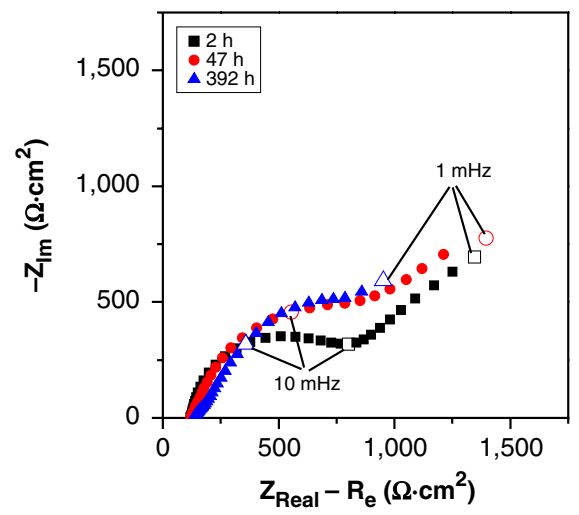

(c)

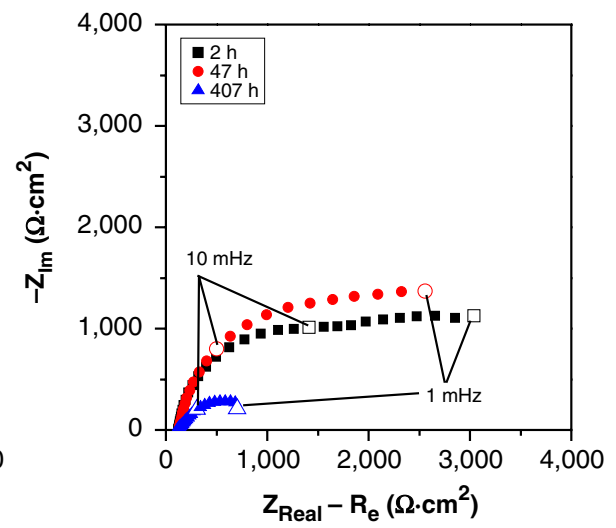

(f)

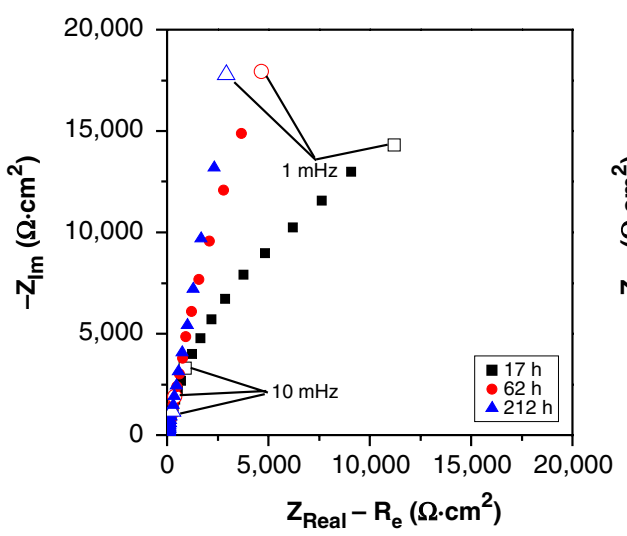

(g)

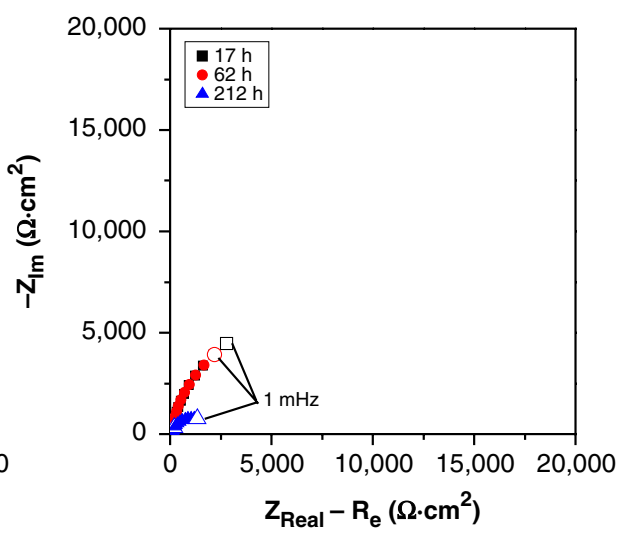

(h)

FIGURE 4. Typical impedance of pure iron in $35 \mathrm{~g} / \mathrm{L} \mathrm{NaCl}$ solution saturated with $\mathrm{H}_{2} \mathrm{~S}$ at (a, b) $100 \mathrm{kPa},(\mathrm{c}, \mathrm{d}) 10 \mathrm{kPa},(\mathrm{e}, \mathrm{f}) 1 \mathrm{kPa}$, and (g, h) $0.1 \mathrm{kPa}$; $(a, c, e, g)$ without and $(b, d, f, h)$ with $\mathrm{O}_{2}$ contamination.

other. They present a high-frequency capacitive loop, possibly followed by a second semicircle at low frequency. This lowfrequency semicircle is hardly visible at $1 \mathrm{kPa} \mathrm{H}_{2} \mathrm{~S}$ and $0.1 \mathrm{kPa} \mathrm{H}_{2} \mathrm{~S}$. A previous article discusses that the impedance behavior of pure iron exposed to $100 \mathrm{kPa} \mathrm{H}_{2} \mathrm{~S}$ is characterized by a two-step anodic reaction with an adsorbed intermediate. ${ }^{14}$ The charge transfer resistance from which corrosion rate could be calculated is represented by the diameter of the high-frequency time constant observed in Nyquist plots. This interpretation is extended to evaluate the charge transfer resistance for all test conditions as a function of time. A more complex model, including a porous film contribution, had to be used to analyze EIS data obtained at
$100 \mathrm{kPa} \mathrm{H}_{2} \mathrm{~S}$, as explained in details in previous articles. ${ }^{5,14}$ From the charge transfer resistances determined from the EIS data above, it is then possible to present the evolution of instantaneous corrosion rates, with the application of the Stern and Geary relationship ( $B=40 \mathrm{mV} /$ decade used here) and Faraday's law. The results obtained are illustrated in Figure 5.

As expected, without $\mathrm{O}_{2}$ contamination, corrosion rates decrease sharply in short exposure periods, and then stabilize for the remaining duration of the experiment. The time window of the initial drop of corrosion rate is comparable to $\mathrm{pH}$ changes, suggesting that kinetics of corrosion are driven by test solution acidity and FeS formation/solution saturation. 


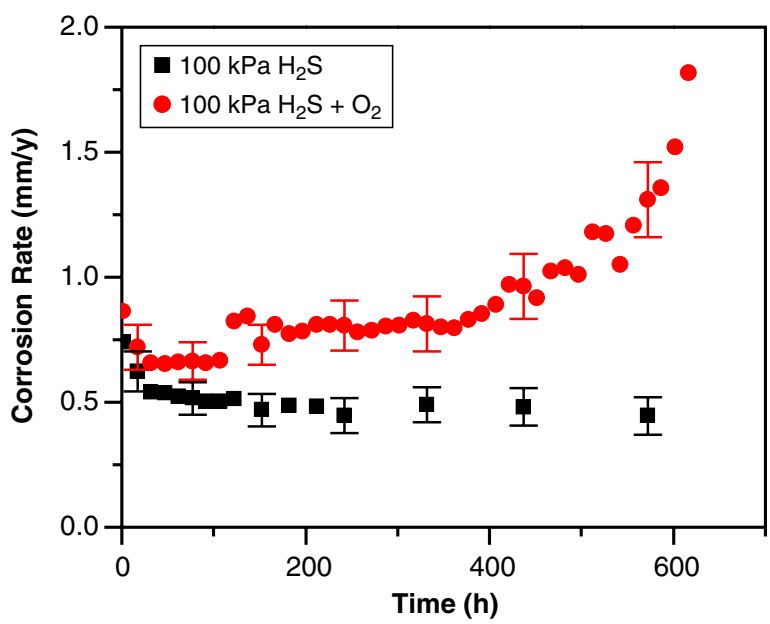

(a)

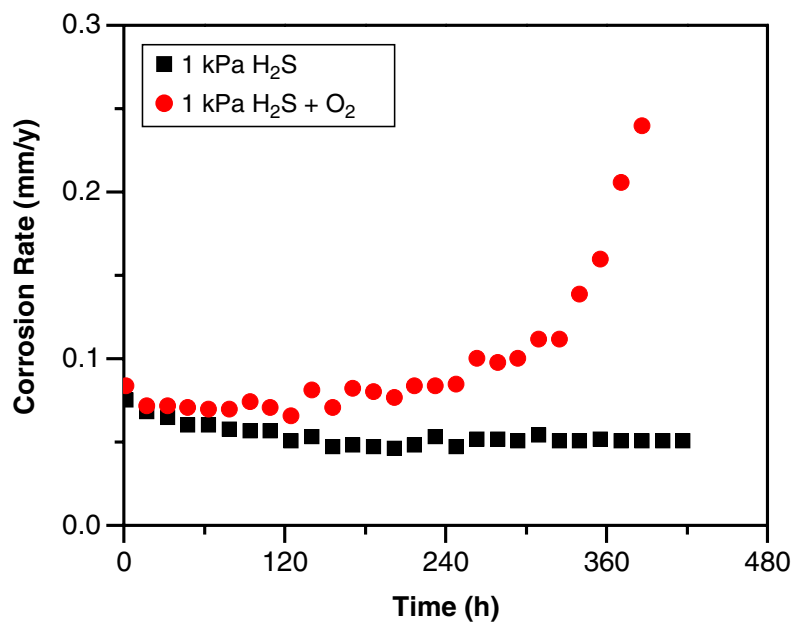

(c)

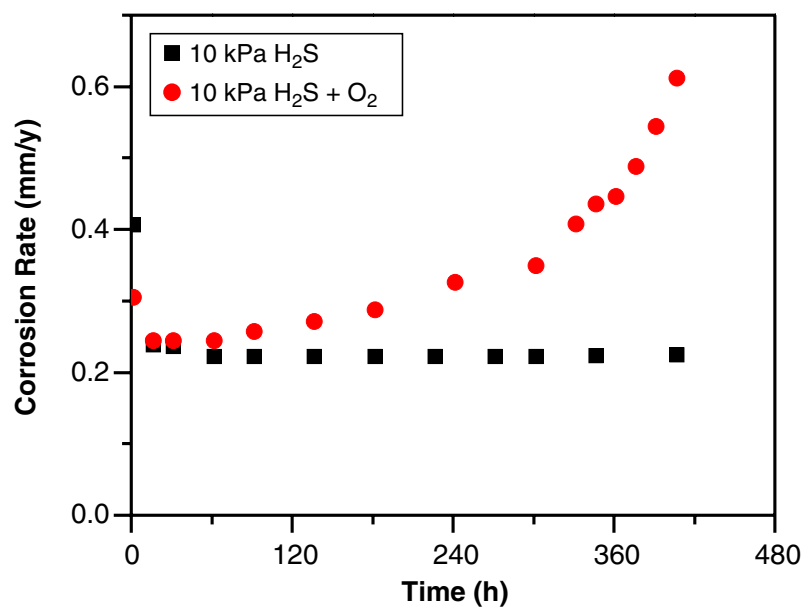

(b)

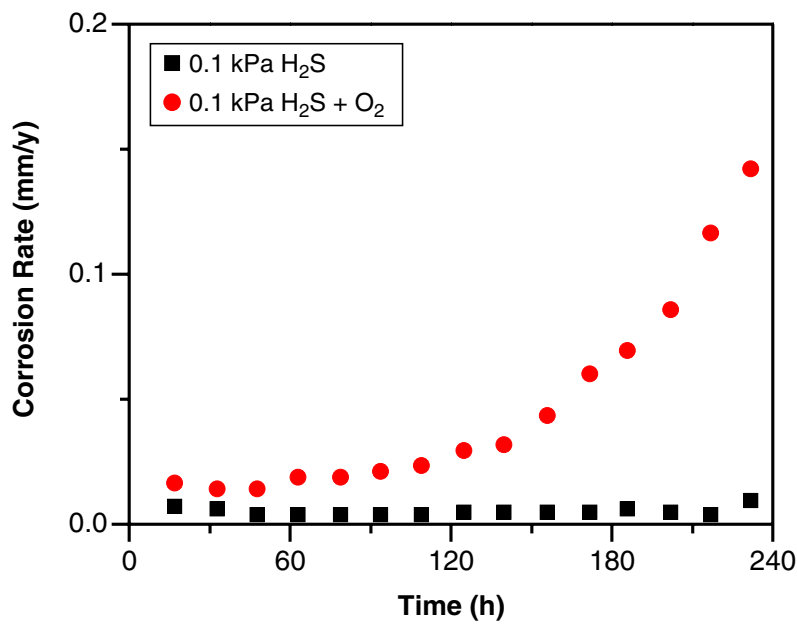

(d)

FIGURE 5. Time evolution of corrosion rates of pure iron determined from EIS analysis.

With $\mathrm{O}_{2}$ contamination, the corrosion rates start to decrease at short exposure times, similarly to the case without $\mathrm{O}_{2}$. However, rather than stabilizing, they then increase sharply as $\mathrm{pH}$ decreases. Looking closely at the profile of the EIS corrosion rates, it is interesting to note that the corrosion rate does not simply increase steadily from the early stages of exposure, but undergoes a sharp transition that imposes a faster rate of corrosion. The trend signifies sudden and enormously increasing rate of reaction that these authors assign to be intimately related to modifications to the protectivity of the sulfide corrosion product films and the deposition of elemental sulfur, as determined by XRD. Field experience suggests that steel corrosion in the presence of elemental sulfur, iron sulfides, and dissolved chlorides can proceed at enormous rates and lead to rapid failure of equipment through deposit galvanic corrosion. ${ }^{4}$ Furthermore, reference to the geothermal power industry's research efforts on the deliberate oxidation of $\mathrm{H}_{2} \mathrm{~S}$ (to eliminate it) through injecting oxygen is highly relevant here. ${ }^{15}$ The reactions of dissolved hydrogen sulfide and oxygen to form thiosulfates, sulfates, and elemental sulfur are suspected to be "autocatalytic," with the possible involvement of cocatalyst radical polysulfido-ions that likely need to build up in concentration. ${ }^{15}$ The $\mathrm{H}_{2} \mathrm{~S}-\mathrm{O}_{2}$ reactions can be catalyzed at active transition metal surfaces (e.g., Ni, $\mathrm{Co}, \mathrm{Fe}$ ), and potentially at iron oxides and iron sulfides. One reproducible experimental feature observed at all $\mathrm{P}_{\mathrm{H}_{2} \mathrm{~S}}$ to support the "autocatalytic oxidation of $\mathrm{H}_{2} \mathrm{~S}$ leading to $\mathrm{S}_{8}$ deposition" hypothesis is a steady rising corrosion rate followed by a very sudden rise at a given moment during immersion. An induction period prior to an unusually high reaction rate is characteristic of an autocatalytic reaction. ${ }^{4,15}$

As noted in Table 2, a significant deviation between weight-loss corrosion rates and electrochemical values is observed at lower $\mathrm{P}_{\mathrm{H}_{2} \mathrm{~S}}$, with the former vastly exceeding the latter. The difference is certainly exacerbated in the case of $\mathrm{O}_{2}$ contamination, reaching a factor of $\times 20$. Upon reflection, the highest corrosion rates of weight-loss coupons, compared to the entry face of permeation membranes, is believed to relate to the different fluid flows that they experience in the experiment cell over the duration of the test (see Figure 2 in Deffo Ayagou, et al. $^{14}$ ). Weight-loss coupons were typically suspended just above the purging gas frit. As a consequence, it is expected that these samples were subjected to a quite unpredictable, turbulent flow if compared against the permeation membrane; the latter is situated at the end of a tube (diameter $=40 \mathrm{~mm}$, length $=60 \mathrm{~mm}$ ) that connects to the main body of the cell. The permeation membrane is concluded to largely experience a laminar, low flow. Considering the distance between the gas 
frit and the permeation membrane (>100 mm), it is quite likely that only the solution reaction $\mathrm{O}_{2}-\mathrm{H}_{2} \mathrm{~S}$ products (thiosulfates and sulfates), rather than dissolved oxygen, interact with the permeation membrane surface. In contrast, the weight-loss coupons were subjected to a direct gas exposure during the first seconds of gas injection. This is suspected to permit the direct oxidation of $\mathrm{H}_{2} \mathrm{~S}$ with dissolved oxygen on these catalytic corrosion coupon surfaces, which explains the presence of elemental sulfur at the surface of the coupons for the tests at $1 \mathrm{kPa}$ and $0.1 \mathrm{kPa} \mathrm{H}_{2} \mathrm{~S}$. In these tests, dissolved $\mathrm{H}_{2} \mathrm{~S}$ concentration is sufficiently weak to allow aqueous and gaseous $\mathrm{O}_{2}$ to reach the coupon surfaces, where it can react with sulfides to form elemental sulfur. As a consequence, the electrochemical measurements that are reported in this paper must be considered representative of test solutions containing $\mathrm{O}_{2}-\mathrm{H}_{2} \mathrm{~S}$ reaction products, rather than a vigorous exposure of oxygen gas to the metal surface. Conversely, a relatively good correlation between both methods of corrosion rate evaluation is generally observed at the higher $\mathrm{P}_{\mathrm{H}_{2} \mathrm{~S}}$ of $100 \mathrm{kPa}$ and $10 \mathrm{kPa}$. This is considered to be an effect of the vast excess of $\left[\mathrm{H}_{2} \mathrm{~S}\right]_{\mathrm{aq}}$ with respect to $\left[\mathrm{O}_{2}\right]_{\mathrm{aq}}$, where the low dissolved oxygen concentration is quickly diminished upon reaction with $\mathrm{H}_{2} \mathrm{~S}$ to form thiosulfates and sulfates. The corrosion of iron in the relatively higher $\mathrm{P}_{\mathrm{H}_{2} \mathrm{~S}}$ media appears to be governed by the effect of the $\mathrm{pH}$ (3.5 to 5 ) and dissolved concentration of $\mathrm{H}_{2} \mathrm{~S}$ on cathodic reactions, rather than flow effects. ${ }^{9}$

The evolution of open-circuit potential values of the pure iron electrode in different partial pressure $\mathrm{H}_{2} \mathrm{~S}$ media is presented in Figure 6, (a) without and (b) with oxygen contamination. Visually, it is clear to see that under oxygen contamination, these values increase considerably more if compared against deaerated conditions. Table 3 lists the change in open-circuit potential between the beginning and after 2 to 4 weeks of sample exposure. As the corrosion rate and open-circuit potential are both increasing, mixed potential theory would suggest that it is the increasing cathodic reaction kinetics that play the important role in corrosion acceleration. The opencircuit potential rise in the oxygen polluted conditions also correlates with the increasing solution acidity (Figure 1). It is suspected that the increase in cathodic corrosion reaction kinetics might arise from increasing $\mathrm{H}^{+}$concentration as well as from Reaction (2) (thiosulfate reduction). Indeed, the role of elemental sulfur cannot be ruled out.

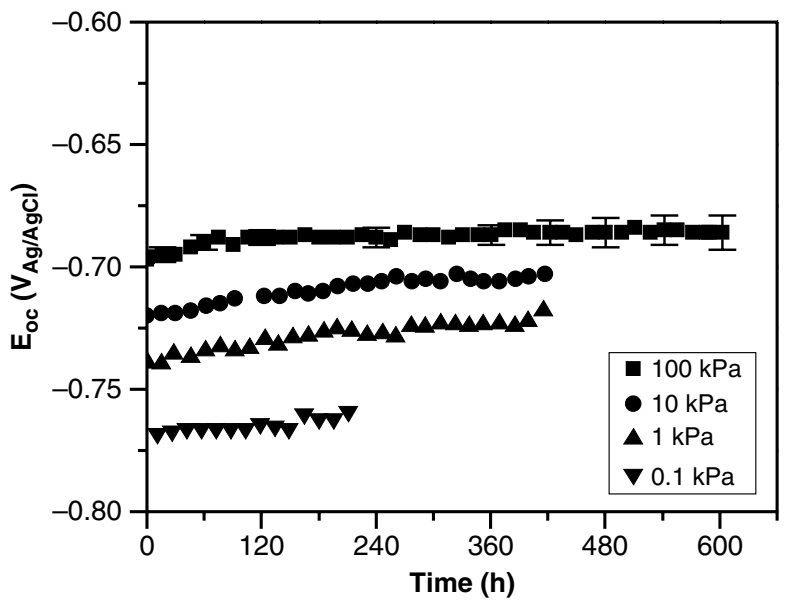

(a)
Figures 7(a) through (h) present the results of the hydrogen permeation tests at different partial pressures of $\mathrm{H}_{2} \mathrm{~S}$, with and without oxygen gas contamination of the solutions. As EIS measurements were performed simultaneously with hydrogen permeation, it is possible to compare the evolution of corrosion current density and hydrogen permeation current density as a function of time through evaluating the hydrogen permeation efficiency $\left(E_{\text {perm }}\right)$, defined as the ratio between permeation current and corrosion current. The validity of its usage in such experiments is outlined in Part $1 .^{5}$

For the studied conditions, it is observed that average permeation currents diminish with decreasing $\mathrm{P}_{\mathrm{H}_{2} \mathrm{~S}}$ (i.e., lower $\left[\mathrm{H}_{2} \mathrm{~S}\right]_{\mathrm{aq}}$ and $\left.\left[\mathrm{H}^{+}\right]_{\mathrm{aq}}\right)$. Quite remarkably, and as already observed in the previous article, permeation efficiencies are close to $100 \%$ for all tests without $\mathrm{O}_{2}$ contamination, albeit more scattering appears at $0.1 \mathrm{kPa} \mathrm{H}_{2} \mathrm{~S}$. For this test condition $\left(0.1 \mathrm{kPa} \mathrm{H}_{2} \mathrm{~S}\right.$ without $\mathrm{O}_{2}$ ), it is believed that corrosion current densities were overestimated, due to insufficient influence of the charge transfer resistance in the frequency range of impedance measurements (Figure 4[g]). In such conditions, permeation current density might be a more reliable indication of corrosion current density than EIS analysis. Such results with no $\mathrm{O}_{2}$ contamination illustrate the strong power of $\mathrm{H}_{2} \mathrm{~S}$ in hydrogen entry promotion, with $100 \%$ efficiency for as low as $0.1 \mathrm{kPa} \mathrm{H}_{2} \mathrm{~S}$. This behavior is observed in very specific hydrogen permeation systems, provided that the entire corrosion current contributes to hydrogen entry (i.e., negligible film protection, hydrogen entry promoters), that there is no impediment to hydrogen entry (i.e., no filming or competitive adsorption), that no hydrogen diffusion limitation in the bulk of the metal occurs (i.e., thin membrane, low trapping), and that the hydrogen extraction is efficient (i.e., $\mathrm{Pd}$ coated). ${ }^{16-17}$

Table 3. Impact of $\mathrm{O}_{2}$ Contamination on Open-Circuit Potential Value Change (from start) of Pure Iron Exposed to $35 \mathrm{~g} / \mathrm{L} \mathrm{NaCl}$ Solution Saturated with $\mathrm{H}_{2} \mathrm{~S}$ at Various Partial Pressures for 2 to 4 Weeks

\begin{tabular}{|l|l|l|l|l|}
\hline $\mathbf{P}_{\mathbf{H}_{2} \mathbf{S}}$ & $\mathbf{1 0 0} \mathbf{k P a}$ & $\mathbf{1 0} \mathbf{~ k P a}$ & $\mathbf{1} \mathbf{~ k P a}$ & $\mathbf{0 . 1} \mathbf{k P a}$ \\
\hline $\mathrm{H}_{2} \mathrm{~S}$ & $+11 \pm 5 \mathrm{mV}$ & $+17 \mathrm{mV}$ & $+21 \mathrm{mV}$ & $+9 \mathrm{mV}$ \\
\hline $\mathrm{H}_{2} \mathrm{~S}+\mathrm{O}_{2}$ & $+40 \pm 15 \mathrm{mV}$ & $+85 \mathrm{mV}$ & $+49 \mathrm{mV}$ & $+43 \mathrm{mV}$ \\
\hline
\end{tabular}

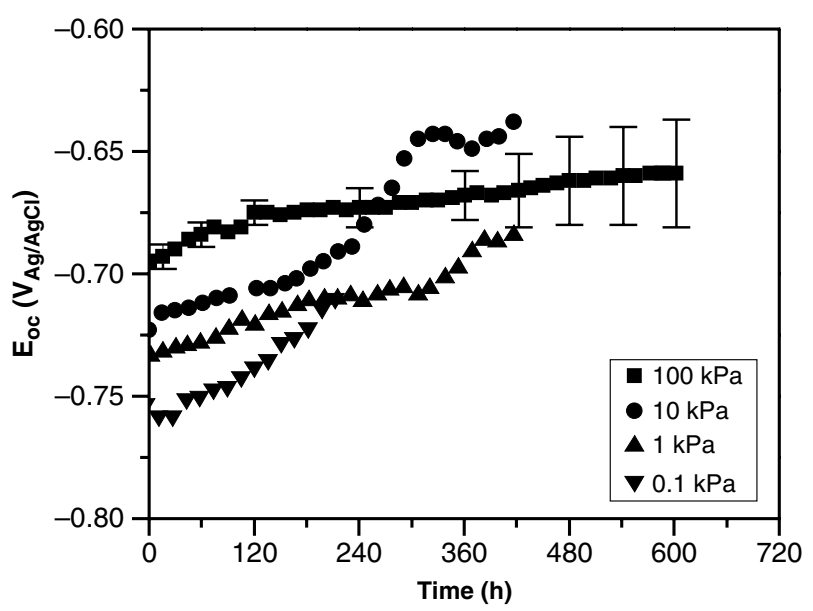

(b)

FIGURE 6. Time evolution of open-circuit potentials of pure iron exposed to $35 \mathrm{~g} / \mathrm{L} \mathrm{NaCl}$ solution saturated with $\mathrm{H}_{2} \mathrm{~S}$ at various partial pressures for 2 to 4 weeks, (a) without oxygen and (b) with oxygen contamination. 


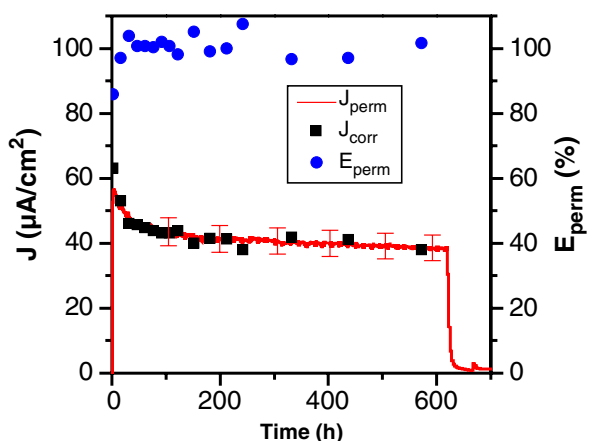

(a)

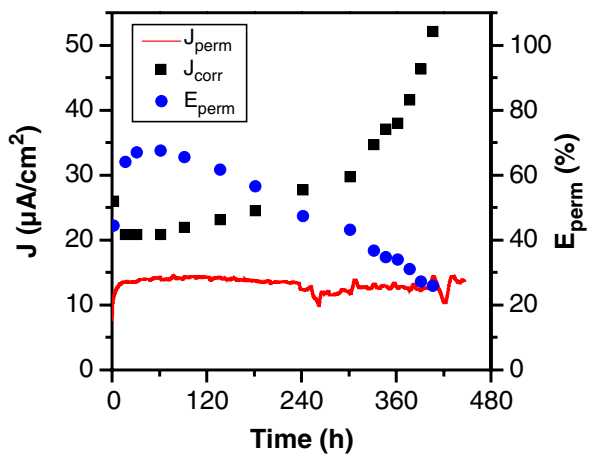

(d)

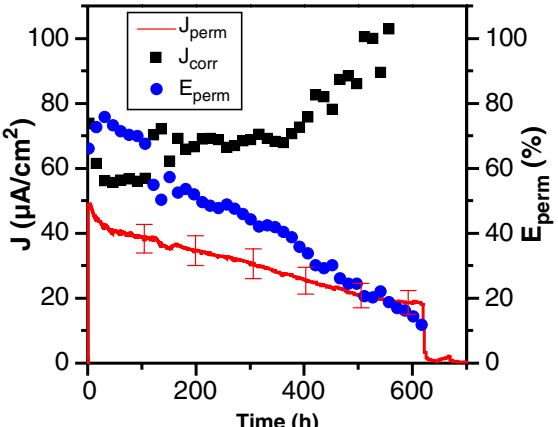

(b)

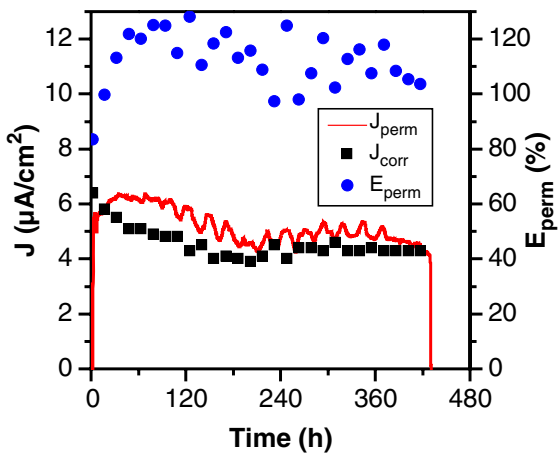

(e)

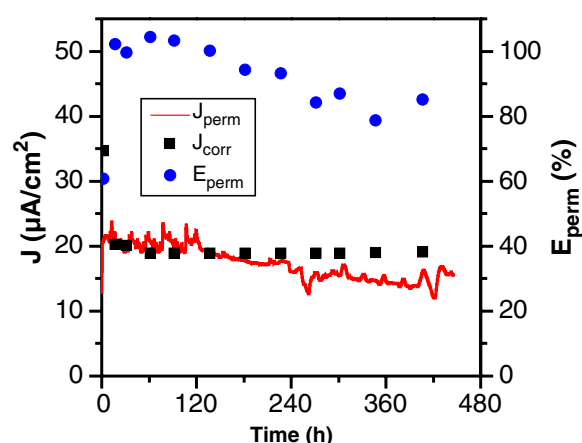

(c)

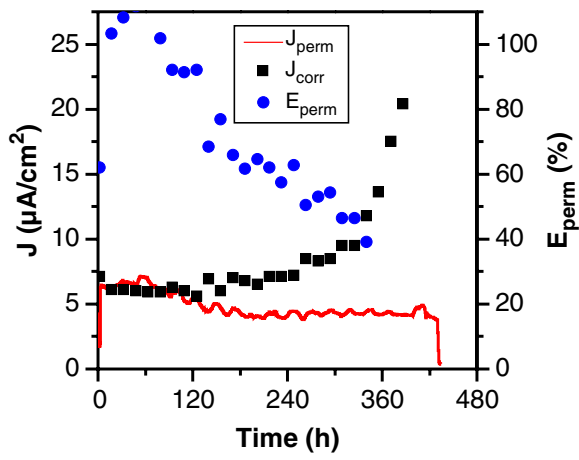

(f)

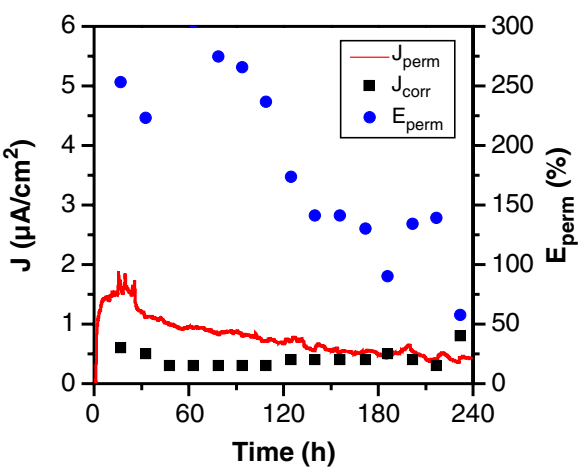

(g)

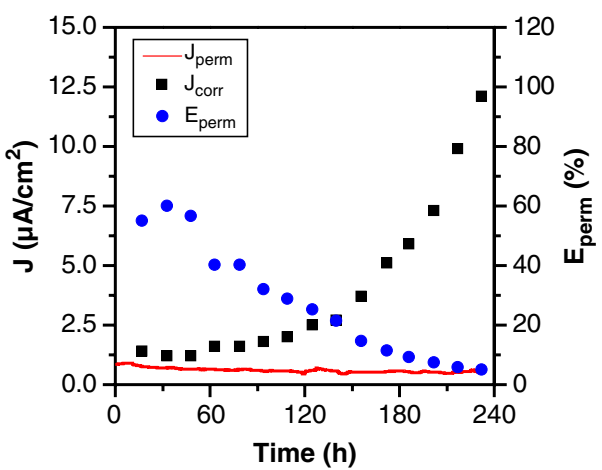

(h)

FIGURE 7. Comparisons between $J_{\text {corr }}$ and $J_{\text {perm, }}$ and evolution of the permeation efficiency, as a function of time. Tests at (a, b) $100 \mathrm{kPa}$, (c, d) $10 \mathrm{kPa},(e, f) 1 \mathrm{kPa}$, and $(g, h) 0.1 \mathrm{kPa},(a, c, e, g)$ without and $(b, d, f, h)$ with $\mathrm{O}_{2}$ contamination.

Conversely, under oxygen contamination, the hydrogen permeation current is always found to be weaker relative to the reference solutions. The previous article ${ }^{5}$ discusses the continuous decrease of the hydrogen permeation current for the $\mathrm{O}_{2}$-polluted $100 \mathrm{kPa}$ system. Interestingly, this is no longer the case for lower $\mathrm{P}_{\mathrm{H}_{2} \mathrm{~S}}$ solutions. Rather, a lower permeation current (hydrogen diffusion) is simply maintained throughout the experiment duration. As the hydrogen extraction setup is always identical, and identical membranes are used, this is almost certainly a limitation on hydrogen uptake in the oxygen-polluted systems. The impact of $\mathrm{O}_{2}$ contamination is better illustrated by $\mathrm{E}_{\text {perm. }}$. Considering this parameter, similar trends are observed whatever the $\mathrm{P}_{\mathrm{H}_{2} \mathrm{~S}}$ considered in the study. At short immersion times, when $\mathrm{O}_{2}-\mathrm{H}_{2} \mathrm{~S}$ reactions have not yet had time to modify the system, high permeation efficiencies are obtained, typically between $60 \%$ and $100 \%$. Then, as $\mathrm{O}_{2}-\mathrm{H}_{2} \mathrm{~S}$ reaction products modify the test solution and the surface scales, a continuous decrease of the permeation efficiency is seen. This decrease is mainly due to the increase of corrosion rate, which takes place at nearly constant $J_{\text {perm, }}$ suggesting the participation of an additional cathodic reaction that drives corrosion without promoting hydrogen entry into the metal. It is expected that this contribution comes from thiosulfate reduction (Reactions [3] and [4]) and the subsequent corrosion acceleration effects of elemental sulfur.

\section{CONCLUSIONS}

The effect of traces of oxygen on the corrosion of, and hydrogen permeation across, pure iron was studied in a $35 \mathrm{~g} / \mathrm{L}$ $\mathrm{NaCl}$ test solution saturated with $\mathrm{H}_{2} \mathrm{~S}$ partial pressures ranging from $100 \mathrm{kPa}$ to $0.1 \mathrm{kPa}$, as a function of time over 2 to 4 weeks. $\mathrm{O}_{2}$ contamination was introduced in a continuous manner in the test gas, at a partial pressure of $1.3 \mathrm{kPa}$ corresponding to 500 mass ppb dissolved $\mathrm{O}_{2}$ at equilibrium. The following conclusions were drawn from this study: 
$>$ With $\mathrm{H}_{2} \mathrm{~S}$ partial pressure from $100 \mathrm{kPa}$ to $0.1 \mathrm{kPa}$, and in the resulting $\mathrm{pH}$ range of 4 to $6, \mathrm{O}_{2}$ contamination modifies the test solution chemistry by forming thiosulfates, and the stable sulfate species. These reactions appear to induce a test solution acidification that would extend to over $1 \mathrm{pH}$ unit over $720 \mathrm{~h}$. $>\mathrm{O}_{2}$ contamination significantly enhances the corrosion of iron in all cases, compared to reference solution without $\mathrm{O}_{2}$. At low $\mathrm{P}_{\mathrm{H}_{2} \mathrm{~S}}$, as the iron surface is placed close to the source of $\mathrm{O}_{2}$ entry, the $\mathrm{H}_{2} \mathrm{~S}-\mathrm{O}_{2}$ oxidation reactions take place at the metal/metal sulfide surface, depositing elemental sulfur, and accelerating corrosion rates by an order of magnitude $(20 x)$ in the process. When the metal surface is sufficiently far to be exposed only to $\mathrm{H}_{2} \mathrm{~S}-\mathrm{O}_{2}$ reaction products, the factor drops to approximately $2 \times$ on average for the time scale of these experiments.

$>$ Without $\mathrm{O}_{2}$ contamination, mackinawite is generally the principal iron sulfide species detected. With $\mathrm{O}_{2}$ contamination at high $\mathrm{P}_{\mathrm{H}_{2} \mathrm{~S}}$, surfaces are revealed to consist of additional iron sulfide (pyrrohtite, troillite) signatures; at lower $\mathrm{P}_{\mathrm{H}_{2} \mathrm{~S}}$, clear diffraction peaks for greigite, magnetite, and elemental sulfur are discerned.

$>$ Without $\mathrm{O}_{2}$ contamination, hydrogen permeation density is found to be in the same range as the corrosion current density, irrespective of the $\mathrm{P}_{\mathrm{H}_{2} \mathrm{~S}}$, implying a 100\% permeation efficiency. This is a clear illustration of the strong hydrogen entry promotion by $\mathrm{H}_{2} \mathrm{~S}$.

- Conversely, with $\mathrm{O}_{2}$ contamination, hydrogen permeation efficiency drops from $60 \%$ to $100 \%$ initially, to as low as $5 \%$ after 2 to 4 weeks. This drop is mainly due to the continuous increase of corrosion rate, indicating that $\mathrm{H}_{2} \mathrm{~S}-\mathrm{O}_{2}$ reactions promote the onset and participation of additional cathodic corrosion reactions.

In the third part of this series of papers, similar experiments will be performed in experimental conditions more representative of industrial applications. Pure iron membrane will be replaced by low alloy steel, and tests will be conducted in acetate buffered solutions.

\section{ACKNOWLEDGMENTS}

The authors express their gratitude to Alexandre Bonneau for his active participation in the implementation of the experimental setup and Remy Mingant, for EIS analysis. The contribution of
IFPEN analysis department in the surface characterization and solution analysis is also greatly acknowledged.

\section{References}

1. ISO 15156-2:2015, "Petroleum and Natural Gas IndustriesMaterials for Use in $\mathrm{H}_{2} \mathrm{~S}$-Containing Environments in Oil and Gas Production - Part 2: Cracking Resistant Carbon and Low Alloy Steels, and the Use of Cast Iron" (Geneva, Switzerland: International Organization for Standardization, 2015).

2. NACE TM0284-2016, "Evaluation of Pipeline and Pressure Vessel Steels for Resistance to Hydrogen-Induced Cracking" (Houston, TX: NACE International, 2016).

3. NACE TM0177-2016, "Laboratory Testing of Metals for Resistance to Sulfide Stress Cracking and Stress Corrosion Cracking in $\mathrm{H}_{2} \mathrm{~S}$ Environments" (Houston, TX: NACE, 2016).

4. J. Boivin, S. Oliphant, "Sulfur Corrosion due to Oxygen Ingress," CORROSION 2011, paper no. 120 (Houston, TX: NACE, 2011).

5. M.D. Deffo Ayagou, J. Kittel, C. Mendibide, C. Duret Thual, K. Belkhadiri, T.T. Mai Tran, E. Sutter, B. Tribollet, N. Ferrando, Corrosion 74, 11 (2018): p. 1192-1202.

6. J.L. Crolet, M. Pourbaix, A. Pourbaix, "The Role of Trace Amounts of Oxygen on the Corrosivity of $\mathrm{H}_{2} \mathrm{~S}$ Media," CORROSION 1991, paper no. 22 (Houston, TX: NACE, 1991).

7. Y. Song, A. Palencsár, G. Svenningsen, J. Kvarekvål, T. Hemmingsen, Corrosion 68 (2012): p. 662-671.

8. N.A. Shvab, V.D. Litovchenko, L.M. Rudkovskaya, Russ. J. Appl. Chem. 80 (2007): p. 1852-1855.

9. Y. Zheng, B. Brown, S. Nesic, Corrosion 70 (2014): p. 351-365.

10. J. Kittel, F. Ropital, F. Grosjean, E.M.M. Sutter, B. Tribollet, Corros. Sci. 66 (2013): p. 324-329.

11. X. Wen, P. Bai, B. Luo, S. Zheng, C. Chen, Corros. Sci. 139 (2018): p. $124-140$

12. G. Schmitt, Corrosion 47 (1991): p. 285-308.

13. M. Gregg, J. Slofstra, E.W. Sudds, D.T. Thill, "Corrosion Experiences and Inhibition Practices Managing Wet Sour Salty Gas Pipeline Environments Contaminated with Sulfur Deposits," CORROSION 2003, paper no. 174 (Houston, TX: NACE, 2003).

14. M.D. Deffo Ayagou, T.T. Mai Tran, B. Tribollet, J. Kittel, E. Sutter, N. Ferrando, C. Mendibide, C. Duret-Thual, Electrochim. Acta 282 (2018): p. 775-783

15. O. Weres, L. Tsao, "Reaction of Hydrogen Sulfide with Oxygen in the Presence of Sulfite," Lawrence Berkeley Laboratory, University of California, LBL-11377, 1983.

16. S. Wach, A.P. Miodownik, J. Mackowiak, Corros. Sci. 6 (1966): p. 271-285.

17. T. Zakroczymski, Z. Szklarska-Smiatowska, M. Smiatowski, Werkst. Korros. 27 (1976): p. 625-630. 